Research Articles

\title{
Sustainable Energy for Aerospace Vessels
}

\author{
${ }^{1}$ Relly Victoria Petrescu, ${ }^{2}$ Raffaella Aversa, ${ }^{3}$ Bilal Akash, ${ }^{2}$ Antonio Apicella and \\ ${ }^{1}$ Florian Ion Tiberiu Petrescu \\ ${ }^{I}$ ARoTMM-IFToMM, Bucharest Polytechnic University, Bucharest, (CE), Romania \\ ${ }^{2}$ Advanced Material Lab, Department of Architecture and Industrial Design, \\ Second University of Naples, 81031 Aversa (CE), Italy \\ ${ }^{3}$ Dean of School of Graduate Studies and Research, American University of Ras Al Khaimah, UAE
}

Article history

Received: 26-10-2017

Revised: 28-10-2017

Accepted: 3-11-2017

Corresponding Author: Florian Ion Tiberiu Petrescu ARoTMM-IFToMM, Bucharest Polytechnic University, Bucharest, (CE), Romania E-mail: scipub02@gmail.com

\begin{abstract}
The advances in solar technology and electric propulsion now offer the promise of new, very capable space transport systems that will allow us to effectively explore the solar system. NASA has developed many concepts of space-powered spacecraft with power levels ranging from tens to hundreds of kilowatts for robotic and asteroid-driven missions and Mars. This paper describes two electrical/chemical propulsion concepts developed over the last 5 years and discusses how they could be used to humanize the solar system. A possible sustainable solution for the supply of spacecraft power would be to achieve and utilization nuclear fusion energy. The paper briefly presents some contributions to obtaining nuclear fusion energy as a viable alternative to current energies. For the energy of spacecraft of the future, the combination of photovoltaic energy (obtained from the stars) and that produced by a nuclear reactor on fusion is essential. NASA is developing a strategy to send a crew to Mars by 2030. To achieve this goal, NASA plans to develop the technology for long-haul flights including advanced transportation work and living systems. Among these technologies, Solar Electric Propulsion (PES) has been identified as very effective in moving large masses through interplanetary space. For decades it has been known that missions outside the low Earth's orbit can be made cost-effective by PSA, but yet such space missions have not yet been done because the manufacturing technology is not advanced enough. NASA's recent investments in solar power systems and propulsion systems have now matured so that the $50 \mathrm{~kW}$ PSA is already ready to be put on flight missions. It has been demonstrated analytically that these technologies can be resized to systems with the power of several hundred kilowatts.
\end{abstract}

Keywords: Electric Propulsion, Solar Technology, Nuclear Fusion Energy, Environmental Protection, Renewable Energy

\section{Introduction}

NASA is developing a strategy to send a crew to Mars by 2030. To achieve this goal, NASA plans to develop the technology for long-haul flights including advanced transportation work and living systems. Among these technologies, solar electric propulsion (PES) has been identified as very effective in moving large masses through interplanetary space.

For decades it has been known that missions outside the low Earth's orbit can be made cost-effective by PSA, but yet such space missions have not yet been done because the manufacturing technology is not advanced enough. NASA's recent investments in solar power systems and propulsion systems have now matured so that the $50 \mathrm{~kW}$ PSA is already ready to be put on flight missions.

It has been demonstrated analytically that these technologies can be resized to systems with the power of several hundred kilowatts.

These technologies are expected to be demonstrated on missions that are increasingly distant from the earth, gaining confidence in this system before embarking on Earth-independent missions. 
These missions will advance the human exploration capability of the current, earth-dependent phase.

\section{Methods and Materials}

Recently, NASA has developed two technologies that are critical to the PES high power system: (1) Highly resistant flexible solar panels and (2) HET magnetic protection systems. Both technologies have been built and tested to demonstrate their availability in PES operation at $50 \mathrm{~kW}$. A key component of these flexible solar panels is their very small mass and very small storage space. A key feature of the propeller is its ability to process a large amount of propellant with a very low degradation factor for High-delta-V missions. Both technologies can be quickly swept at a much higher power level. Flexible solar panels are based on new structures that offer a large, small volume solar collector area. To accomplish this, tensile nets instead of rigid panels were used to reduce weight and storage. Two models of flexible panels were built.

One with a rectangular launch design called "RollOut Solar Array" (ROSA).

The second is a fan-fold circular design called "MegaFlex from ATK orbit".

ROSA is deployed by a dampened release of stressenergy stored in rolled-up composite arms extending a photovoltaic sheet attached to a rod connecting the outer tips of the two arms. MegaFLex runs through a motorized band that first extends an articulated arm and then rotates a $360^{\circ}$ swing panel to unroll a photovoltaic blanket. The arm increases the radius of the circular tree without increasing the length of the panel. The development engineering unit (UID) of each design was built to produce $20 \mathrm{~kW}$ nominal power using the triplejunction photovoltaic cell standard. Acoustic and vibratory tests were made with the photovoltaic cells in operation to determine the resistance to launch (EDHEEnergy and Power, NASA), (see Fig. 1-2).

Deployment tests were performed in vacuum at + 60 degrees to determine autonomous functionality under relevant conditions.

Strength tests and resistance were also made.

These tests have convinced NASA that both designs are ready to be incorporated into a mission that normally requires $40 \mathrm{~kW}$ of solar power.

This system is intended for the First Lunar Outpost regenerative fuel cells (Fig. 3). The materials used are of the highest quality, and they use nanotechnologies (Aversa et al., 2017a-e, 2016a-o; Berto et al., 2016a-d; Cataldo, 2006; Gruener, 2006; Mirsayar et al., 2017; Petrescu and Petrescu, 2016a-c, 2013a-d, 2012a-d, $2011 \mathrm{a}-\mathrm{b}$; Petrescu, 2012a-c, 2009; Petrescu and Calautit, 2016a-b; Petrescu et al., 2016a-c).

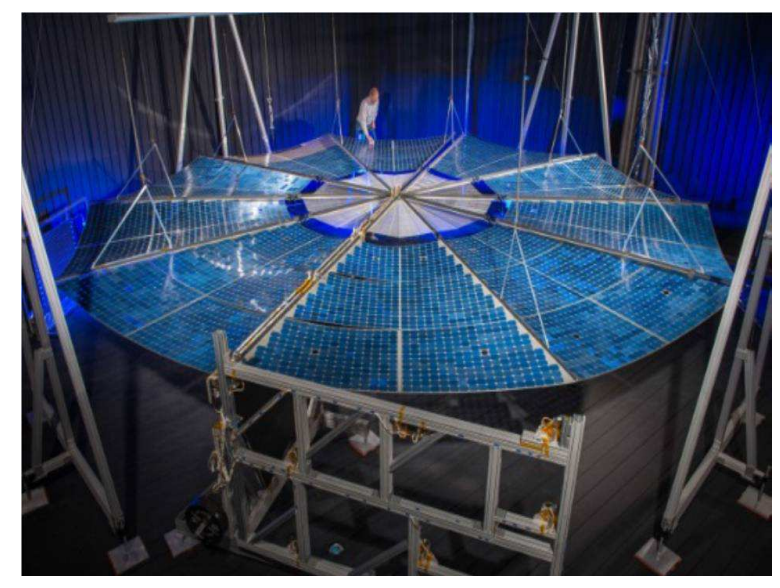

Fig. 1: The development engineer unit (UID) of each design has been built to produce $20 \mathrm{~kW}$ nominal power using the photovoltaic triplet-junction standard

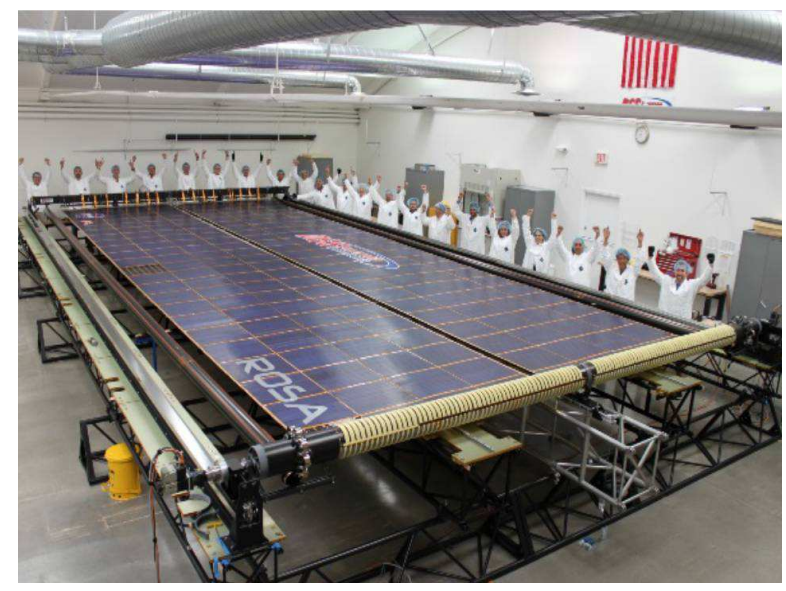

Fig. 2: UID deployed and unloaded in a thermal configuration used in a vacuum

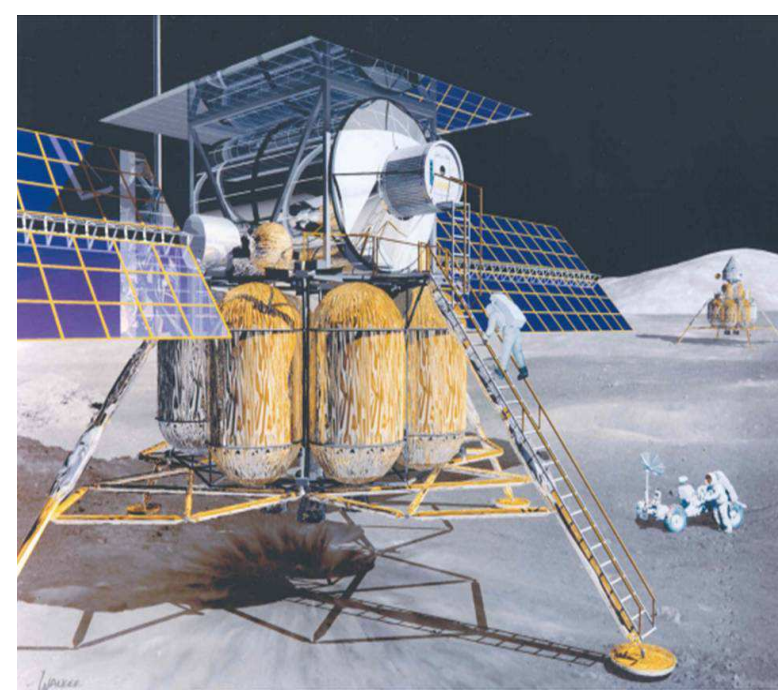

Fig. 3: First Lunar Outpost regenerative fuel cells 


\section{Results}

In the summer of 2005, Glenn demonstrated the first fully closed-loop regenerative fuel cell ever operated. It completed five continuous day and night cycles. Those five days of operation were the result of several years of hard work. The team's diligence paid off by proving a regenerative fuel cell's potential as an energy storage device for aerospace solar power systems.

Since the demonstration in 2005 , the team has modified and upgraded much of the software, circuitry, and hardware to make the system run more reliably.

In November 2006, at Johnson Space Center, Houston, TX, was presented the "Lunar exploration" to ITEA Human Exploration Project Authors, (Fig. 4-5). In addition to these tests, analyses were made to determine the feasibility of measuring these solar panels by up to $125 \mathrm{~kW}$ per "wing".

The MegaFlex concept can be increased by increasing the diameter of the panel and the number of struts.

Analyses show that two 30-meter wings can bring an extra $440 \mathrm{~kW}$ of power using a reverse metamorphic (MMI) photovoltaic multi-junction and still fit into the test chamber and the $8.4 \mathrm{~m} 25 \mathrm{~m}$ armchair that is needed at launch.

Electric propellers are based on a magnetically shielded magnetic shield that prevents material erosion by using a monolithic discharge chamber, a centrally mounted cathode, and a counterflow flow collector with a uniform flow and protection against deposition of backflush material.

This very low erosion design was chosen to make very high xenon propulsion while operating at only 12.5 $\mathrm{kW}$ with a very high pulse.

Two UIDs were designed and built: One for the other tests and the other for vacuum tests.

The tests confirm that the magnetic circuits of the propellers have been protected by the protective shield to prevent erosion within favorable electromagnetic limits. Hot-Fire Tests confirm the absence of voltage failures during operation. The measurements on the characterization tests showed surface erosion and plasma distribution.

The erosion rate of the discharge channel walls and the magnetic circuit components were measured and found to be in line with the predicted values.

Environmental tests, including random and vacuum vibration tests, confirmed that the propeller meets the structural and thermal specifications expected from a 50$\mathrm{kW}$ PES mission.

This propeller has shown increased efficiency from 6.7 to $12.5 \mathrm{~kW}$ operating at a specific high pulse from 2000 to $3000 \mathrm{~s}$.

Validated models predict over $10 \mathrm{t}$ of xenon as a propulsion agent, enough to withstand 50,000 h.

Because it is hard to imagine that a ship relies exclusively on solar energy, huge efforts are still being made to build a fusion-based nuclear energy source.

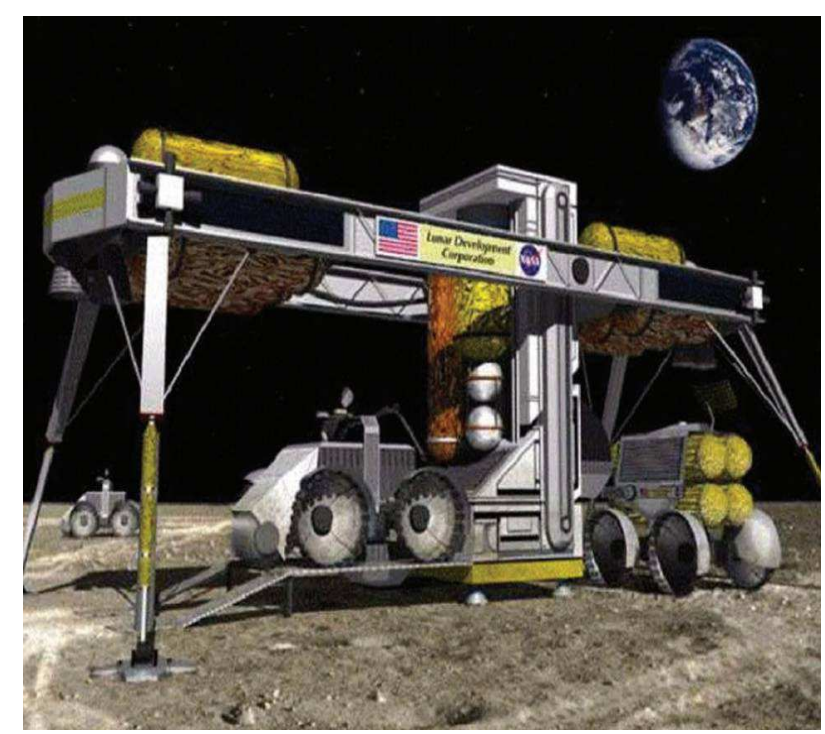

Fig. 4: Steel frame and modular structures

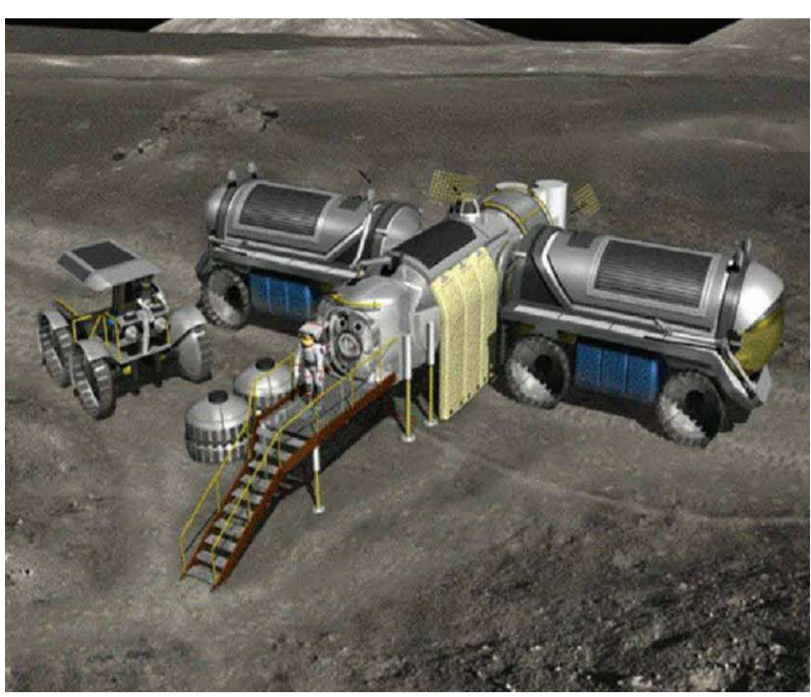

Fig. 5: Steel frame and modular structures

Nuclear fusion sometimes referred to as thermonuclear fusion, is a process where two light atomic nuclei come together to form a heavier nucleus. This reaction is at work in a natural way in the Sun and most stars of the Universe.

The fusion of light nuclei releases enormous amounts of energy from the attraction between the nucleons due to the strong interaction (nuclear binding energy). Fusion is with nuclear fission one of the two main types of nuclear reactions applied.

The mass of the new atom obtained by the fusion is less than the sum of the masses of the two light atoms. In the process of fusion, part of the mass is transformed into energy in its simplest form: heat. This loss is explained by the Einstein known formula $\mathrm{E}=\mathrm{mc} 2$. 
One of its interests is to be able to obtain theoretically much more energy: first to the mass of "fuel" equal, the fusion releases three to four times more energy than fission. Then, the "fuel" stock is much larger: the oceans naturally contain such a mass of deuterium (33 $\mathrm{g} / \mathrm{m}^{3}$ ) that they could theoretically satisfy the current energy consumption of the human species for one hundred million Years $\left(1 \mathrm{~m}^{3}\right.$ of water can potentially provide as much energy as the combustion of $700 \mathrm{t}$ of oil).

Despite research carried out around the world since the 1950s, no industrial application of fusion to energy production has yet succeeded, apart from nuclear weapons with the H-bomb, since this application does not aim at containing and controlling the reaction produced. There are, however, some other less mediated uses, such as neutron generators.

Unlike nuclear fission, the fusion products themselves (mainly helium 4) are not radioactive, but when the reaction is used to emit fast neutrons, they can transform the nuclei that capture them into isotopes that some of them can be radioactive.

We must not confuse nuclear fusion with the fusion of the core of a nuclear reactor, which is a particularly formidable nuclear accident.

The only nuclear reaction carried out on an industrial scale up to now is that of nuclear fission. With all that, there were some nuclear accidents and the raw material used as fuel and residue also is radioactive, energy from nuclear fission represented for humanity a necessary evil. She managed to prevent an energy major crisis for humanity.

We were not allowed back in the caves as it has started with millions of years ago. We do not want to give up nor to our current homes comfortable, that we make them be warm in winter and cooling them in summer you (to feel us better).

The energy for fission helped us to avoid a crisis disaster and in addition to prolonging the life of the hydrocarbons. Today we are a little better.

The advanced technologies allowed us to implement new renewable energies, sustainable, green and friendly for man and to the environment. It is better to continue to implement other and other central solar energy, wind or hydro. But if we have a moment of rest, it does not mean that we must give up to a beautiful dream of humanity, namely the one to bring the sun on the Earth. In other words, we must continue to try to devise and achieve the nuclear fusion, industrial and peaceful.

\section{Discussion}

The advances in solar technology and electric propulsion now offer the promise of new, very capable space transport systems that will allow us to effectively explore the solar system. NASA has developed many concepts of space-powered spacecraft with power levels ranging from tens to hundreds of kilowatts for robotic and asteroid-driven missions and Mars.

This paper describes two electrical/chemical propulsion concepts developed over the last 5 years and discusses how they could be used to humanize the solar system.

A possible sustainable solution for the supply of spacecraft power would be to achieve and utilization nuclear fusion energy.

The paper briefly presents some contributions to obtaining nuclear fusion energy as a viable alternative to current energies.

For the energy of spacecraft of the future, the combination of photovoltaic energy (obtained from the stars) and that produced by a nuclear reactor on fusion is essential.

NASA is developing a strategy to send a crew to Mars by 2030. To achieve this goal, NASA plans to develop the technology for long-haul flights including advanced transportation work and living systems. Among these technologies, Solar Electric Propulsion (PES) has been identified as very effective in moving large masses through interplanetary space.

For decades it has been known that missions outside the low Earth's orbit can be made cost-effective by PSA, but yet such space missions have not yet been done because the manufacturing technology is not advanced enough.

NASA's recent investments in solar power systems and propulsion systems have now matured so that the 50 $\mathrm{kW}$ PSA is already ready to be put on flight missions. It has been demonstrated analytically that these technologies can be resized to systems with the power of several hundred kilowatts.

\section{Conclusion}

Recently, NASA has developed two technologies that are critical to the PES high power system: (1) Highly resistant flexible solar panels and (2) HET magnetic protection systems. Both technologies have been built and tested to demonstrate their availability in PES operation at $50 \mathrm{~kW}$. A key component of these flexible solar panels is their very small mass and very small storage space. A key feature of the propeller is its ability to process a large amount of propellant with a very low degradation factor for High-delta- $\mathrm{V}$ missions. Both technologies can be quickly swept at a much higher power level. Flexible solar panels are based on new structures that offer a large, small volume solar collector area. To accomplish this, tensile nets instead of rigid panels were used to reduce weight and storage. Two models of flexible panels were built.

One with a rectangular launch design called "RollOut Solar Array" (ROSA).

The second is a fan-fold circular design called "MegaFlex from ATK orbit".

ROSA is deployed by a dampened release of stressenergy stored in rolled-up composite arms extending a 
photovoltaic sheet attached to a rod connecting the outer tips of the two arms. MegaFLex runs through a motorized band that first extends an articulated arm and then rotates a $360^{\circ}$ swing panel to unroll a photovoltaic blanket. The arm increases the radius of the circular tree without increasing the length of the panel. The development engineering unit (UID) of each design was built to produce $20 \mathrm{~kW}$ nominal power using the triplejunction photovoltaic cell standard. Acoustic and vibratory tests were made with the photovoltaic cells in operation to determine the resistance to launch (EDHEEnergy and Power, NASA).

\section{Acknowledgement}

We acknowledge and thank $\mathrm{Mr}$ Taher M. AbuLebdeh, Associate Prof at North Carolina A and T State Univesity, United States and Mr Muftah H. El-Naas PhD MCIC FICCE QAFCO Chair Professor in Chemical Process Engineering Gas Processing Center College of Engineering Qatar University and Ms Shweta Agarwala, Senior Research Scientist at Singapore Center for 3D Printing Nanyang Technological University Singapore for their suggestions and comments.

\section{Author's Contributions}

All the authors contributed equally to prepare, develop and carry out this manuscript.

\section{Ethics}

This article is original and contains unpublished material. The corresponding author confirms that all of the other authors have read and approved the manuscript and no ethical issues involved.

\section{References}

Aversa, R., F.I.T. Petrescu, R.V. Petrescu and A. Apicella, 2016a. Biomimetic FEA bone modeling for customized hybrid biological prostheses development. Am. J. Applied Sci., 13: 1060-1067. DOI: 10.3844/ajassp.2016.1060.1067

Aversa, R., D. Parcesepe, R.V. Petrescu, G. Chen and F.I.T. Petrescu et al., 2016b. Glassy amorphous metal injection molded induced morphological defects. Am. J. Applied Sci., 13: 1476-1482.

DOI: 10.3844 /ajassp.2016.1476.1482

Aversa, R., R.V. Petrescu, F.I.T. Petrescu and A. Apicella, 2016c. Smart-factory: Optimization and process control of composite centrifuged pipes. Am. J. Applied Sci., 13: 1330-1341.

DOI: 10.3844 ajassp.2016.1330.1341
Aversa, R., F. Tamburrino, R.V. Petrescu, F.I.T. Petrescu and M. Artur et al., $2016 \mathrm{~d}$. Biomechanically inspired shape memory effect machines driven by muscle like acting NiTi alloys. Am. J. Applied Sci., 13: 1264-1271. DOI: 10.3844/ajassp.2016.1264.1271

Aversa, R., E.M. Buzea, R.V. Petrescu, A. Apicella and M. Neacsa et al., 2016e. Present a mechatronic system having able to determine the concentration of carotenoids. Am. J. Eng. Applied Sci., 9: 1106-1111. DOI: 10.3844/ajeassp.2016.1106.1111

Aversa, R., R.V. Petrescu, R. Sorrentino, F.I.T. Petrescu and A. Apicella, 2016f. Hybrid ceramo-polymeric nanocomposite for biomimetic scaffolds design and preparation. Am. J. Eng. Applied Sci., 9: 1096-1105. DOI: 10.3844/ajeassp.2016.1096.1105

Aversa, R., V. Perrotta, R.V. Petrescu, C. Misiano and F.I.T. Petrescu et al., 2016g. From structural colors to super-hydrophobicity and achromatic transparent protective coatings: Ion plating plasma assisted $\mathrm{TiO} 2$ and $\mathrm{SiO} 2$ Nano-film deposition. Am. J. Eng. Applied Sci., 9: 1037-1045.

DOI: 10.3844/ajeassp.2016.1037.1045

Aversa, R., R.V. Petrescu, F.I.T. Petrescu and A. Apicella, 2016h. Biomimetic and evolutionary design driven innovation in sustainable products development. Am. J. Eng. Applied Sci., 9: 1027-1036. DOI: 10.3844/ajeassp.2016.1027.1036

Aversa, R., R.V. Petrescu, A. Apicella and F.I.T. Petrescu, 2016i. Mitochondria are naturally micro robots-a review. Am. J. Eng. Applied Sci., 9: 991-1002. DOI: 10.3844/ajeassp.2016.991.1002

Aversa, R., R.V. Petrescu, A. Apicella and F.I.T. Petrescu, 2016j. We are addicted to vitamins $\mathrm{C}$ and E-A review. Am. J. Eng. Applied Sci., 9: 1003-1018. DOI: 10.3844/ajeassp.2016.1003.1018

Aversa, R., R.V. Petrescu, A. Apicella and F.I.T. Petrescu, 2016k. Physiologic human fluids and swelling behavior of hydrophilic biocompatible hybrid ceramo-polymeric materials. Am. J. Eng. Applied Sci., 9: 962-972.

DOI: 10.3844/ajeassp.2016.962.972

Aversa, R., R.V. Petrescu, A. Apicella and F.I.T. Petrescu, 20161. One can slow down the aging through antioxidants. Am. J. Eng. Applied Sci., 9: 1112-1126. DOI: 10.3844/ajeassp.2016.1112.1126

Aversa, R., R.V. Petrescu, A. Apicella and F.I.T. Petrescu, 2016m. About homeopathy or «Similia similibus curentur $\gg$. Am. J. Eng. Applied Sci., 9: 1164-1172. DOI: 10.3844/ajeassp.2016.1164.1172

Aversa, R., R.V. Petrescu, A. Apicella and F.I.T. Petrescu, 2016n. The basic elements of life's. Am. J. Eng. Applied Sci., 9: 1189-1197.

DOI: 10.3844/ajeassp.2016.1189.1197 
Aversa, R., F.I.T. Petrescu, R.V. Petrescu and A. Apicella, 2016o. Flexible stem trabecular prostheses. Am. J. Eng. Applied Sci., 9: 1213-1221. DOI: $10.3844 /$ ajeassp.2016.1213.1221

Aversa, R., R.V.V. Petrescu, A. Apicella and F.I.T. Petrescu, 2017a. Nano-diamond hybrid materials for structural biomedical application. Am. J. Biochem. Biotechnol., 13: 34-41. DOI: 10.3844/ajbbsp.2017.34.41

Aversa, R., R.V. Petrescu, B. Akash, R.B. Bucinell and J.M. Corchado et al., 2017b. Kinematics and forces to a new model forging manipulator. Am. J. Applied Sci., 14: 60-80. DOI: 10.3844/ajassp.2017.60.80

Aversa, R., R.V. Petrescu, A. Apicella, I.T.F. Petrescu and J.K. Calautit et al., 2017c. Something about the $\mathrm{V}$ engines design. Am. J. Applied Sci., 14: 34-52. DOI: 10.3844/ajassp.2017.34.52

Aversa, R., D. Parcesepe, R.V.V. Petrescu, F. Berto and G. Chen et al., 2017d. Process ability of bulk metallic glasses. Am. J. Applied Sci., 14: 294-301. DOI: 10.3844/ajassp.2017.294.301

Aversa, R., R.V.V. Petrescu, B. Akash, R.B. Bucinell and J.M. Corchado et al., 2017e. Something about the balancing of thermal motors. Am. J. Eng. Applied Sci., 10: 200.217. DOI: 10.3844/ajeassp.2017.200.217

Berto, F., R.V.V. Petrescu and F.I.T. Petrescu, 2016a A review of recent results on $3 \mathrm{D}$ effects. Am. J. Eng. Applied Sci., 9:1247-1260.

Berto, F., R.V.V. Petrescu and F.I.T. Petrescu, 2016b Three-dimensional in bonded joints: A short review. Am. J. Eng. Applied Sci., 9:1261-1268.

Berto, F., A. Gagani, R.V.V. Petrescu and F.I.T. Petrescu, 2016c Key-hole notches in isostatic graphite: A review of some recent data. Am. J. Eng. Applied Sci., 9:1292-1300.

Berto, F., A. Gagani, R. Aversa, R.V.V. Petrescu and A. Apicella et al., 2016d Multiaxial fatigue strength to notched specimens made of 40CrMoV13.9. Am. J. Eng. Applied Sci., 9:1269-1291.

Cataldo, R., 2006 Overview of planetary power system options for education. ITEA Human Exploration Project Authors, 2006, at Glenn Research Center. Brooke Park, $\mathrm{OH}$.

EDHE-Energy and Power. NASA. https://www.nasa.gov/audience/foreducators/topnav/ materials/listbytype/HEP_Engineering.html.

Gruener, J.E., 2006. Lunar exploration (Presentation to ITEA Human Exploration Project Authors, November 2006, at Johnson Space Center). Houston, TX.
Mirsayar, M.M., V.A. Joneidi, R.V.V. Petrescu, F.I.T. Petrescu and F. Berto, 2017. Extended MTSN criterion for fracture analysis of soda lime glass. Eng. Fracture Mechanics, 178: 50-59. DOI: 10.1016/j.engfracmech.2017.04.018

Petrescu, F.I. and R.V. Petrescu, 2011 a. Memories about Flight. 1st Edn., CreateSpace, pp: 652.

Petrescu, F.I. and R.V. Petrescu, 2011b. Mechanical Systems, Serial and Parallel - Course (in romanian), LULU Publisher, London, UK, 124 pages, ISBN 978-1-4466-0039-9, Romanian edition.

Petrescu, R.V. and F.I.T. Petrescu, 2012a. Northrop. Books on Demand, ISBN-13: 978-3848209323, pp: 142.

Petrescu, F.I. and R.V. Petrescu, 2012b. New Aircraft II. 1st Edn., Books on Demand, pp: 138.

Petrescu, F.I. and R.V. Petrescu, 2012c Mecatronicasisteme seriale si paralele. Create Space publisher, USA, ISBN 978-1-4750-6613-5, pp: 128.

Petrescu, F.I. and R.V. Petrescu, 2012d. Kinematics of the planar quadrilateral mechanism. Engevista, 14: 345-348.

Petrescu, R.V. and F.I. Petrescu, 2013a. Lockheed Martin. 1st Edn., CreateSpace, pp: 114.

Petrescu, R.V. and F.I. Petrescu, 2013b. Northrop. 1st Edn., CreateSpace, pp: 96.

Petrescu, R.V. and F.I. Petrescu, 2013c. The Aviation History or New Aircraft I Color. 1st Edn., CreateSpace, pp: 292.

Petrescu, F.I. and R.V. Petrescu, 2013d. Cinematics of the 3R Dyad, Engevista, 15: 118-124.

Petrescu, F.I. and R.V. Petrescu, 2016a Parallel moving mechanical systems kinematics. ENGE-VISTA, 18:455-491.

Petrescu, F.I. and R.V. Petrescu, 2016b Direct and inverse kinematics to the anthropomorphic robots. ENGEVISTA, 18: 109-124.

Petrescu, F.I. and R.V. Petrescu, 2016c. Dynamic cinematic to a structure 2R. Revista Geintec-Gestao Inovacao E Tecnologias, 6: 3143-3154.

Petrescu, F.I.T. and J.K. Calautit, 2016a. About Nano fusion and dynamic fusion, Am. J. Applied Sci., 13: 261-266.

Petrescu, F.I. and J.K. Calautit, 2016b About the light dimensions. Am. J. Applied Sci., 13:321-325. DOI: 10.3844/ajassp.2016.321.325

Petrescu, F.I.T., 2009. New aircraft. Proceedings of the 3rd International Conference on Computational Mechanics, Oct. 29-30, Brasov, Romania.

Petrescu, F.I.T., 2012a. Cold Nuclear Fusion, USA, Create Space, ISBN/EAN13: 1478234261/9781478234265, pp: 80.

Petrescu, F.I.T., 2012b. Particle Annihilation-A source of renewable energy? 
Petrescu, F.I.T., 2012c. Particle annihilation-a source of renewable energy? Infinite Energy.

Petrescu, R.V.V., R. Aversa, A. Apicella, F. Berto and S. Li et al., 2016a Ecosphere protection through green energy. Am. J. Applied Sci., 13: 1027-1032.

Petrescu, F.I.T., A. Apicella, R.V.V. Petrescu, S.P. Kozaitis and R.B. Bucinell et al., $2016 \mathrm{~b}$. Environmental protection through nuclear energy. Am. J. Applied Sci., 13:941-946.

Petrescu, R.V., R. Aversa, A. Apicella and F.I. Petrescu, 2016c. Future medicine services robotics. Am. J. Eng. Applied Sci., 9: 1062-1087.

\section{Source of Figures}

Fig. 1:

Source: https://www.nasa.gov/pdf/475484main_HEP_I_HS.pdf Fig. 2:

Source: https://www.nasa.gov/pdf/475484main_HEP_I_HS.pdf Fig. 3:

Source: https://www.nasa.gov/pdf/475484main_HEP_I_HS.pdf Fig. 4:

Source: https://www.nasa.gov/pdf/475484main_HEP_I_HS.pdf Fig. 5:

Source: https://www.nasa.gov/pdf/475484main_HEP_I_HS.pdf 